\title{
RELATIONSHIP BETWEEN EDUCATION LEVEL AND MATERNAL TIME AVAILABILITY WITH COMPLETENESS OF BASIC IMMUNIZATION DURING THE COVID-19 PANDEMIC IN SUKOHARJO
}

\author{
Aurellia Cahya Maharani ${ }^{1}$, Astika Gita Ningrum ${ }^{2}$, Mahendra Tri Arif Sampurna ${ }^{3}$ \\ ${ }^{1}$ Departemen of Midwifery Education, Faculty of Medicine University Airlangga 60132, Surabaya, East Java, Indonesia \\ ${ }^{2}$ Departemen of Midwifery Education, Faculty of Medicine University Airlangga 60132, Surabaya, East Java, Indonesia \\ ${ }^{3}$ Departemen of Pediatrics, Faculty of Medicine University Airlangga 60132, Surabaya, East Java, Indonesia
}

Corresponding Author : astika.gita.n@fk.unair.ac.id

\begin{abstract}
Background: Immunization is an attempt to generate immunity against a particular disease so that when exposed to disease, the body will not get sick or if sick only in mild conditions. This study aimed to determine the relationship between education level and time availability with the completeness of basic immunization during the COVID-19 pandemic in Sukoharjo Regency, Indonesia. Methods: This type of research is analytic observational with a sample of 100 mothers with children aged 0-20 months in Sukoharjo Regency. The research sample was collected through a non-probability sampling technique with quota sampling. Data were collected using questionnaires and MCH handbook in April-October 2021. Data analysis was carried out using the Chi-square test. Results: The research findings showed that the proportion of children who received complete basic immunization was $66 \%$. The results of the bivariate analysis of basic immunization completeness with education level obtained $\mathrm{p}$-value $=0.001(\mathrm{p}<0.05)$ and time availability obtained $\mathrm{p}$-value $=$ 0.004 ( $p$ < 0.05). Conclusion: Based on the analysis results, it can be concluded that there is a relationship between the level of education and the availability of time with the completeness of basic immunization during the COVID-19 pandemic in Sukoharjo Regency.
\end{abstract}

Keywords: basic immunization; education; time availability

\section{Introduction}

Immunization is an attempt to generate immunity against a particular disease so that when exposed to an infection, the body will not get sick or if sick only in mild conditions [1]. Currently, immunization has helped prevent 2-3 million deaths annually caused by diphtheria, pertussis, tetanus, measles and influenza [2]. The government requires the implementation of complete basic immunization for every child as stipulated in the Regulation of the Minister of Health no. 12 Year 2017 [3]. Diseases that can be prevented through immunization include tuberculosis, diphtheria, tetanus, hepatitis B, pertussis, measles, rubella, polio, inflammation of the brain's lining, and pneumonia [1].

The emergence of the COVID-19 pandemic in Indonesia since March 2020 has changed all challenges and aspects of life. In the health sector, services are focused on preventing and handling COVID-19 so that other health services such as maternal and child health, including immunization for children, are disrupted [4][5]. The survey in 2020 stated that as many as 23 million children lost immunization opportunities, $60 \%$ of them came from 10 countries, one of which was Indonesia [6]. Likewise, data on the analysis of immunization coverage in Indonesia showed a decrease of $0.5 \%-87 \%$ in the period January-April 2020 compared to 2019 [7]. Of course, this will risk extraordinary events (KLB) caused by diseases that can be prevented by immunization (PD3I) [8].

The importance of immunization can be seen from the number of reductions in lifting and even the absence of cases of PD3I such as smallpox, polio and tetanus [9]. However, if you look at the data presented in the health profile of the province of Central Java in 2019, it is found that the number of suspected PD3I suspects is still quite high above the minimum standard. The profile also shows that the highest prevalence of suspected measles cases is in Sukoharjo Regency, with 385 cases [1].

Looking at the immunization coverage figures according to pocketbook for the first quarter of 2021, there is a significant difference between the target for complete basic immunization coverage in Central Java and Sukoharjo Regency during the COVID-19 pandemic. At 0-7 days, HB immunization coverage in Central Java was $18.7 \%$ with a target of $23.7 \%$, in Sukoharjo $16.4 \%$. BCG immunization coverage in Central Java was $18.7 \%$ with a target of 23.7\%, in Sukoharjo $15.7 \%$, 
DPT-HB-HIB 3 immunization coverage in Central Java was $18.2 \%$ with a target of $23.7 \%$, in Sukoharjo $16.9 \%$, Polio immunization coverage in Central Java was $17.8 \%$ with Sukoharjo $16,9 \%$, and the Measles-Rubella immunization coverage in Central Java was $11.9 \%$ with a target of $23.75 \%$, in Sukoharjo it was $19.5 \%$ so that a red graph of the Sukoharjo area immunization coverage was obtained.

Education, in general, is all efforts that are planned to influence other people, whether individuals, groups or communities, so that they do what is expected to be long lasting and permanent, because it is based on awareness. . Education level is known to have a significant effect on complete basic immunization coverage [10]. Higher education mothers will have increased knowledge and understanding about their children's health services, including basic immunization.

Time availability is closely related to people's opportunities to visit health facilities [11]. In the case of immunization, the availability of time for mothers to deliver their children's immunizations is an essential factor in influencing the completeness of their children's basic immunizations. Mothers who are busy with their work think more about work, so they don't have time to immunise their children [12]. Therefore, this study aims to determine the relationship between the level of education and the availability of mother's time with the completeness of basic immunization during the COVID-19 pandemic in Sukoharjo Regency, Indonesia.

\section{Methods}

This type of research is an observational analytic study with a cross-sectional design that uses primary data obtained through questionnaires and secondary data through the MCH handbook. This research was conducted in April - October 2021 in the Sukoharjo Regency, Indonesia.This research was approved by the research ethics committee of Faculty of Medicine, Universitas Airlangga (No.189/EC/KEPK/FKUA/2021).

The sampling technique used non-probability sampling with quota sampling. The sample used in this study amounted to 100 respondents. Inclusion criteria are mothers who have children aged 0-20 months, have an MCH handbook, are domiciled in Sukoharjo Regency, mothers who are not illiterate and are willing to be research respondents. The data were analysed statistically using Chi-square. Analysis was used to determine the relationship between education level and availability of time with the completeness of basic immunization. The value used as a benchmark for the relationship between the two variables is p-value $<0.05$.

\section{Results}

The research was conducted in the district of Sukoharjo, Indonesia. In this study, 100 respondents had children aged 020 months. Data were obtained through research questionnaires and the MCH handbook for April - October 2021.

\section{Univariate Analysis}

\section{Characteristics Associated with Basic immunization}

Table 1. Characteristics Related to Completeness of Basic Immunization During a Pandemic in Sukoharjo.

\begin{tabular}{|c|c|c|c|}
\hline No & Variable & Frequency (f) & Percentage (\%) \\
\hline \multirow[t]{3}{*}{1} & Education & & \\
\hline & a. Low & 45 & 45 \\
\hline & b. High & 55 & 55 \\
\hline \multirow[t]{3}{*}{2} & Knowledge & & \\
\hline & a. Less & 32 & 32 \\
\hline & Enough & 68 & 68 \\
\hline \multirow[t]{3}{*}{3} & Attitude & & \\
\hline & Negative & 37 & 37 \\
\hline & b. Positive & 63 & 63 \\
\hline \multirow[t]{3}{*}{4} & Place Availability & & \\
\hline & a. Far & 18 & 18 \\
\hline & b. Near & 82 & 82 \\
\hline \multirow[t]{3}{*}{5} & Cost Availability & & \\
\hline & a. Expensive & 76 & 76 \\
\hline & b. Cheap & 24 & 24 \\
\hline \multirow[t]{3}{*}{6} & Time Availability & & \\
\hline & a. Not Available & 2 & 2 \\
\hline & b. Available & 98 & 98 \\
\hline \multirow[t]{3}{*}{7} & Husband Support & & \\
\hline & a. Doesn't Support & 12 & 12 \\
\hline & Support & 88 & 88 \\
\hline
\end{tabular}




\begin{tabular}{|c|c|c|c|}
\hline \multirow[t]{3}{*}{8} & Family Support & & \\
\hline & a. Doesn't Support & 13 & 13 \\
\hline & b. Support & 87 & 87 \\
\hline \multirow[t]{3}{*}{9} & Health Workers Support & & \\
\hline & a. Doesn't Support & 51 & 51 \\
\hline & b. Support & 49 & 49 \\
\hline \multirow[t]{3}{*}{10} & Health Cadres & & \\
\hline & a. Doesn't Support & 34 & 34 \\
\hline & b. Support & 66 & 66 \\
\hline 11 & Use of MCH handbook & & \\
\hline & a. Not use & 18 & 18 \\
\hline & b. Use & 82 & 82 \\
\hline Total & & 100 & 100 \\
\hline
\end{tabular}

Based on table 1, the results show that the majority of mothers with a higher education level are 55 people $(55 \%)$, maternal knowledge of basic immunization is enough 68 people $(68 \%)$, positive mother attitudes towards basic immunization during the COVID-19 pandemic 63 people $(63 \% 82$ people $(82 \%)$, mothers think that immunization costs are expensive 76 people (76\%), mothers have the time available to take their children to immunization service places 98 people (98\%), mothers who have husbands support immunization as many as 88 people $(88 \%)$, mothers who have families who support basic immunization as many as 87 people (87\%), mothers who feel there is no support from health workers for essential immunization services 51 people (51\%), mothers who feel supported from health cadres 66 people (66\%). The majority of mothers used the $\mathrm{MCH}$ handbook as many as 82 people $(82 \%)$.

\section{Frequency Distribution of Respondents Based on Immunization Status}

Table 2. Distribution of Respondents Based On Completeness of Basic Immunization during the Pandemic Period in Sukoharjo.

\begin{tabular}{lll}
\hline Basic immunization Status & Frequency $(\mathbf{f})$ & Percentage (\%) \\
\hline Incomplete & 34 & 34 \\
Complete & 66 & 66 \\
Total & $\mathbf{1 0 0}$ & $\mathbf{1 0 0}$ \\
\hline
\end{tabular}

Based on table 2, the results obtained are that from 100 respondents, most children with complete basic immunization status were 66 people (66\%). The minority had incomplete basic immunization status as 34 people (34\%).

\section{Bivariate Analysis}

Table 3. Relationship Between Education Level and Maternal Time Availability with Completeness of Basic Immunization.

\begin{tabular}{|c|c|c|c|c|c|c|}
\hline \multirow{3}{*}{\multicolumn{2}{|c|}{$\begin{array}{c}\text { Independent Variables and } \\
\text { Categories }\end{array}$}} & \multicolumn{4}{|c|}{ Basic immunization } & \multirow{3}{*}{ P-value } \\
\hline & & \multicolumn{2}{|c|}{ Incomplete } & \multicolumn{2}{|c|}{ Complete } & \\
\hline & & $\mathbf{F}$ & $\%$ & $\mathbf{F}$ & $\%$ & \\
\hline \multicolumn{7}{|c|}{ Education } \\
\hline & Less & 23 & 51,1 & 22 & 48,9 & 0,001 \\
\hline & High & 11 & 20 & 44 & 80 & \\
\hline \multicolumn{7}{|c|}{ Time Availability } \\
\hline a. & Not Available & 4 & 100 & 0 & 0 & 0,004 \\
\hline b. & Available & 30 & 31,25 & 66 & 68,75 & \\
\hline
\end{tabular}

Based on table 3, it can be seen that the majority of mothers with low education have incomplete immunization status, namely 23 people $(51.1 \%)$, mothers with high levels of education have complete immunization status, namely 44 people $(80 \%)$. Meanwhile, all mothers who did not have the time to bring their children to immunize had incomplete child immunization status, namely 4 people (100\%), and mothers who had the majority of time available for complete child immunization status as many as 66 people $(68.75 \%)$. The Chi-square test results showed that the independent variables, namely the level of education and the availability of mother's time, had p values $=0.001$ and 0.04 or $p$-value $<0.05$. 


\section{Discussion}

\section{- Relationship between Education Level and Completeness of Basic Immunization}

Based on the study results, it showed that from 100 respondents, the majority of mothers with low levels of education had incomplete basic immunization status as many as 23 people $(51.1 \%)$. In contrast, mothers with higher education had complete basic immunization status as many as 44 people $(80 \%)$. The results of the Chi-square test obtained p-value $=$ 0.001 ( $\mathrm{p}$-value $<0.05$ ). This means a relationship between the mother's education level and the completeness of the child's basic immunization.

The results of this study are in line with research by Rambe \& Zai (2019), with the title "Relationship Between Mother's Level of Formal Education and Infant's Basic immunization Status in the Lolofitu Moi Health Center area", which states that there is a relationship between the mother's formal education level and the completeness of the infant's basic immunization status [13]. Likewise, in his research, Simatupang (2020) said a significant relationship between a mother's education and the completeness status of basic immunization in children with a p-value $=0.004$ [14].

The level of education that a person gets from formal school can affect a person's knowledge. Education is essential in influencing a person's ability to think, digest and understand a problem. In the context of health, education can help a mother or a group of people in addition to increasing knowledge as well as increasing awareness of mothers to immunize their children, of course, this awareness will have a significant impact on the completeness of basic immunizations for children [15].

Based on the study results and the theoretical description above, according to the researcher's assumptions, the completeness of immunization is influenced by several factors: the mother's level of education. Mothers with a high level of education will affect their knowledge and attitudes to encourage mothers' awareness to provide complete basic immunization.

\section{- $\quad$ Relationship between Availability of Mother's Time and Completeness of Basic Immunizations}

The study results showed that out of 100 respondents, all mothers who did not have the time to take their children to the immunization service centre had incomplete basic immunization status as many as four people (100\%). In contrast, the mothers who had the time available to take their children to the immunization service center were the majority. With complete basic immunization status, as many as 66 people (68.75). The results of the Chi-square test obtained p-value $=$ 0.004 ( $\mathrm{p}$-value <0.05). This means that there is a relationship between the mother's availability to take her child to the immunization service center and the completeness of basic immunization for children.

The results of this study are in line with the research of Edayani \& Suryawati (2019), with the title "Barriers to Immunization Coverage in Children in North Aceh Regency", which shows that many factors inhibiting the provision of basic immunization to children are incomplete, one of which is time constraints. [16]. This was also conveyed in Hastuty's research (2020) which showed that mothers who work for a living would reduce the availability of time to pay attention to children, one of which is taking their children to immunization services so that it has a direct impact on the incompleteness of children's basic immunizations [17].

Based on the study results and the description above, the authors assume that time availability is related to the completeness of children's basic immunizations. Time constraints can occur in mothers who have a high workload, one of which is a mother who is also the breadwinner of the family.

\section{Conclusion}

Based on research conducted on 100 respondents on "The Relationship between Education Level and Maternal Time Availability with Completeness of Basic immunization During the COVID-19 Pandemic in Sukoharjo", it was concluded that the level of education and availability of mother's time had a relationship with the completeness of children's basic immunizations. The story of education has a significant relationship, namely, the higher the education level of a mother, the higher the level of understanding of immunization. It affects mothers' awareness to provide complete basic immunizations for their children. Likewise, with the availability of time for mothers to take their children to immunization services, mothers who have free time will prioritise their children's health to fulfil basic immunization coverage.

\section{Acknowledgement}

The researcher would like to thank the supervising lecturers who have guided me in this research, the Sukoharjo district government who has allowed me to do research, and the respondents willing to help with this research. 


\section{Reference}

[1] Dinas Kesehatan Provinsi Jawa Tengah, "Profil Kesehatan Provinsi Jateng Tahun 2019," Dinas Kesehat. Provinsi Jawa Teng., vol. 3511351, no. 24, p. 61, 2019, [Online]. Available:

https://dinkesjatengprov.go.id/v2018/storage/2020/09/Profil-Jateng-tahun-2019.pdf.

[2] WHO, "Vaccines and immunization," 2020. https://www.who.int/health-topics/vaccines-andimmunization\#tab=tab_1 (accessed Dec. 11, 2021).

[3] K. RI, Profil Kesehatan Indonesia, vol. 1, no. 4. 2018.

[4] S. Kirmani and A. Saleem, "Impact of COVID-19 pandemic on paediatric services at a referral centre in Pakistan: lessons from a low-income and middle-income country setting," vol. 106, no. 7, 2021, doi: 10.1136/archdischild2020-319424.

[5] T. Roberton et al., "Early estimates of the indirect effects of the COVID-19 pandemic on maternal and child mortality in low-income and middle-income countries: a modelling study," Lancet Glob. Heal., vol. 8, no. 7, pp. e901-e908, 2020, doi: 10.1016/S2214-109X(20)30229-1.

[6] "Vaccination and Immunization Statistics - UNICEF DATA." https://data.unicef.org/topic/childhealth/immunization/ (accessed Dec. 12, 2021).

[7] Kementrian Kesehatan Republik Indonesia, "Buletin Surveilans PD3I \& Imunisasi," pp. 11-11, 2020.

[8] Kementerian Kesehatan Republik Indonesia and UNICEF, "Imunisasi Rutin pada Anak Selama Pandemi COVID19 di Indonesia : Persepsi Orang tua dan Pengasuh Agustus 2020,” pp. 1-16, 2020, [Online]. Available: https://www.unicef.org/indonesia/reports/rapid-assessment-immunization-services-indonesia]\%0AImunisasi.

[9] "Imunisasi Lengkap Indonesia Sehat - P2P Kemenkes RI.” http://p2p.kemkes.go.id/imunisasi-lengkap-indonesiasehat/ (accessed Dec. 13, 2021).

[10] W. Sari and M. Nadjib, "Determinan Cakupan Imunisasi Dasar Lengkap pada Penerima Program Keluarga Harapan,” J. Ekon. Kesehat. Indones., vol. 4, no. 1, pp. 1-9, 2019, doi: 10.7454/eki.v4i1.3087.

[11] E. Puspita, E. Oktaviarini, and Y. D. P. Santik, "PERAN KELUARGA DAN PETUGAS KESEHATAN DALAM KEPATUHAN PENGOBATAN PENDERITA HIPERTENSI DI PUSKESMAS GUNUNGPATI KOTA SEMARANG,”J. Kesehat. Masy. Indones., vol. 12, no. 2, pp. 25-32, 2017.

[12] H. M. Pakpahan and D. Silalahi, "HUBUNGAN PENGETAHUAN IBU DENGAN PEMBERIAN IMUNISASI DASAR PADA BALITA DI DESA UJUNG RAMBE KECAMATAN BANGUN PURBA KABUPATEN DELI SERDANG," J. Darma Agung Husada, vol. 8, pp. 92-98, 2021.

[13] nova linda Rambe and sri puspita natalia Zai, "HUBUNGAN TINGKAT PENDIDIKAN FORMAL IBU DENGAN STATUS IMUNISASI DASAR BAYI DI WILAYAH PUSKESMAS LOLOFITU MOI,” J. Ilm. Kebidanan IMELDA, vol. 5, no. 1, pp. 594-598, 2019.

[14] M. Simatupang, "Faktor-Faktor yang Mempengaruhi Ibu Terhadap Status Imunisasi Dasar pada Bayi Usia 12-24 Bulan di Desa Nauli Kecamatan Sigumpar Kabupaten Toba Samosir Tahun 2019," J. Gentle Birth, vol. 3, no. 2, pp. 33-45, 2020, [Online]. Available: https://garuda.ristekbrin.go.id/documents/detail/1745965.

[15] Zulfikar and L. Muslimah, "Hubungan Pengetahuan Dan Sikap Ibu Dengan Kelengkapan Imunisasi Dasar Pada Bayi di Wilayah Kerja Puskesmas Bies Kabupaten Aceh Tengah Relationship Between Knowledge and Attitude of Mother and Completeness of Basic immunization for Babies in the Working Ar," J. Healthc. Technol. Med., vol. 7, no. 1, pp. 214-224, 2021.

[16] S. Edayani and I. Suryawati, "Hambatan Cakupan Imunisasi Pada Anak Di Kabupaten Aceh Utara," Idea Nurs. J., vol. 10, no. 3, pp. 50-57, 2019, doi: 10.52199/inj.v10i3.19759.

[17] M. Hastuty, "Hubungan Pengetahuan dan Pekerjaan Ibu Dengan Kelengkapan Imunisasi Dasar Balita Di Posyandu Desa Kasang Wilayah Kerja UPTD Kesehatan Lubuk Jambi ...,” J. Doppler, vol. 4, no. 1, pp. 10-17, 2020, [Online]. Available: https://journal.universitaspahlawan.ac.id/index.php/doppler/article/view/671. 